\title{
An Assessment of the Guidance and Counselling Programme in Secondary Schools at Mzilikazi District in Bulawayo Metropolitan Province
}

\author{
Printah Printer Nkala \\ Department of Counselling Zimbabwe Open UniversityP O Box 3550 Bulawayo Region Zimbabwe
}

\begin{abstract}
This study sought to assess the Guidance and CounsellingProgrammeinMzilikazi District situatedof the Bulawayo Metropolitan Province. The purpose of the study was to determine the extent to which Guidance and Counselling services prepare secondary school students to achieve social, personal and academic development and make informed career decisions compatible with their individual needs and abilities. Schools were mandated to provide and direct adolescent learners away from participating in anti-social behaviours such as drug and alcohol abuse, prostitution and irresponsible sexual behaviours such as the spread of HIV/AIDS pandemic, homosexuality, gangsterism, violence, and truancy. A descriptive survey was chosen for this study. Survey questionnaires with closed and open-ended questions and semi-interview guides were used to solicit views, perceptions and opinions on the benefits of Guidance and CounsellingProgrammes. A population of 6000 students and 150 teachers was divided into categories through stratified random sampling. One hundred students, thirty teachers and five heads of secondary schools participated in the study. The study revealed that $80 \%$ of the secondary schools in Mzilikazi District had not yet complied with the Ministry of Primary and Secondary Educationon the implementation of the programme. Lack of qualified teachers, stationary, books and relevant facilities like counselling rooms were found to be major barriers inhibiting the implementation of Guidance and Counselling services. The findings also revealed that most of the students are ignorant of the existence of such services which could be the major cause of high rates of delinquency, truancy, alcohol and drug abuse and teenage pregnancies. Therefore, the study concluded that secondary students have not benefited from the programme. Recommendations made include that the Ministry of Primary and Secondary Education should provide adequate resources before considering the implementation of Guidance and CounsellingProgramme in schools.

Keywords: Guidance, Counselling, secondary school students, Bulawayo Metropolitan Province
\end{abstract}

\section{Background to the Study}

The global concernsrelatedtoGuidanceandCounselling services in schools has resulted in a number of studies being carried out internationally regardingthe benefits of Career- Guidance and Counseling services (CGCS). Literaturefrom the past four decades confirms availability of CGCSor programs around the world, including Hong Kong, Britain, United States of America, and Japan to name a few (Taylor, 1971; Paisley and McMahon, 2001; Yee and Brennan, 2004; Yagi, 2008).For example, in Malaysia, Halim, (1999) observed that Guidance and Counselling services help students to overcome social, psychological, cultural and educational problems that arisefrom the rapid economic and cultural changes. In the European Union, the European Centre for the Development of Vocational Training (CEDEFOP) conducted several studies thatfocused on the provision of quality guidance and counselling services among member countries (Bulgarelli, 2003). In the Asia-Pacific region, several researchers confirmed that there are fundamental differences in the implementation of guidance and counsellingprogrammes between the West and Asia-Pacific region as well as among countries themselves (Othman \&Awang, 1993: Zhang, Hu \&Pope, 2002:Tatsuno, 2002). While Guidance and Counsellingis an easily accessible service in many developed countries, its benefits are not yet adequately exploited in developing and third world countries (Hiebert\&Bezanson,2002).In some countries the provision of CGCSservicesisconsidered a luxury that should only be made available largely to choice of subjects (Gysbers\&Henderson, 2001).

In Africa, the concept of Guidance and Counselling although relatively new in educational systems, has been embraced by most governments (UNESCO, 2001). Althoughmost African countries recognize the essential role of organizedGuidanceandCounsellingProgrammes, there are limited research studies conducted to assessthe effectiveness of the programmed services being implemented to improve the students' decision making processes that lead to improved future benefits (Biswalo, 1996; Folkman and Moskowit, 2004). In Malawi, Maluwa (1998) in Chireshe, (2006) reveals that Career-Guidance and Counselling services help students to better understand their own interests, abilities and potentials; and how to develop them fully and subsequently 
make informed career choice decisions. With similar benefits in Kenya, Guidance and Counselling was formally introduced in institutions of learning in 1971 (Muture and Ndambuki, 2004).Guidance and CounsellinginTanzaniais regarded a redundant and lacking trained personnel to provide effective services (Biswalo, 1996). However, what the conclusion from Tanzania lacks is an answer to the question: How will the benefits of the programmes look like if the government took the initiative to train personnel that provide the services? In this study, I view this conclusion as uniformed decision that lacks empirical judgments. From this brief overview, literature reveals that the CGCServices to date are still patchy and ineffective in schools because decision makers and policy makers are not well informed. Studies by Flisher, Zieger, Chalron, Leger and Robertson (2006) revealed that in South Africa there is a prevalence of risk taking adolescents attending secondary education. In another study conducted in South Africa, to assess the challenges faced by schools, it was revealed that inadequate financial and human resources and lack of knowledge on the part of the implementers were the major barriers (Mahlangu, 2011). Similar studies have also been carried out by Navin (1989) in Botswana and UNESCO (1998) in Zambia. According to Sima (2004) Guidance andCounselling became popular especially with the advent of HIV/AIDS. Many people including educationistsassumedCGCS services should only be made available to individuals infected or affected by HIV/AIDS (Sima, 2004). This study seeks to reveal the effectiveness of guidance and counselling services in Zimbabwe's urban and peri-urban secondary schools which are situated in Bulawayo Metropolitan Province.

In Zimbabwe, a few studies have been carried out to assess the benefits of using Career Guidance and Counselling services in secondary schools. Badza, (2005) studied the perceptions held by studentsand teachers towards the implementation and effectiveness of Guidance and Counselling in Mwenezi East District secondary schools, while Chivonivoni's2006study investigated the state of school guidance and counselling in ChiredziNorth.Maturuve (2004) studied the problems faced by school counsellors in the implementation of the Guidance and CounsellingProgramme in Masvingo District, and Chireshe (2006) assessed the effectiveness of school guidance and counselling services in Zimbabwean Secondary Schools while doing his doctoral studies. After a thorough search for related literature on the same topic, google search engines and various library searches, all turned out to be these few studies, and tothe best of myknowledge, no other similar study has been carried out in Zimbabwe's urban environment specifically to confirm the effectiveness of the programme in urban set-ups like Bulawayo Metropolitan Secondary Schools. This left me with the clear license to carry out this current study.

Adolescents in diverse cultures around the world have historically benefitted from the presence of 'informal' counsellors both within the school system as well as from those provided within the community (UNESCO, 2009). The psychosocial problems faced by students are mainly solved by families, more or less as private family affairs. Parents and relatives counseled their children on all matters of life, personal projects management and ways of solving daily problems (Biswalo, 1996). Traditionally, guidance and counselling has always been done without any formal training or knowledge obtained from formal school system but rather through experience, age and wisdom (Amukoa,1984).In most African families, the general guidance and counselling was the duty of senior members of the family, parents, uncles, aunts, and grandparents. Today, as the pressure of the socio-economic and political factors continue, informal counsellinghasbecome eroded andoutdated as people in their communities have become more individualistic (Amir and Latiff, 1984; Chang, 2000; Cook, Heppner and O'Brien, 2002). Migrations of people from rural to urban areas and from country to country, modernization and urbanization have all resulted in a sense of isolation among the youth who have lost traditional familial social networks (Chang, 2000). Traditional cultures, beliefs, values and social relations in the traditional societies have been eroded by international cultural influences through television, social media, music and other toxic influences (Brewer, 1981: Wash, 2004). All these changes leave the youthsand the society at large confused about which models should be followed, hence the need for guidance and counselling services at secondary schools level (House and Hayes, 2002). Guidance and Counselling services provide decision making ideas, direct and advice adolescent students in their relationships, between health and the environment, productive skills, knowledge, skills and attitudes that lead to success in life (Bulus, 1986; Makinde, 1987;Muti and Ndambuki, 2003).

Rice and Leffert (1997: 19) reveal that today's parents look at schoolsfor the provisionoftheir children with personal, social, educational and career guidance. Nziramasanga (1999) in Zimbabwe revealed that because of many socio-economic and political pressures imposed on the family today, parents tend to dedicatelittle time totheir children to allow for the necessary guidance. The study by UNESCO (2002) concurs with Nziramasanga's(1999)findings that Native African parents today have become more concerned with earning moneysuchthat they have simply become less occupied with their traditional roles and practices that formerly contributed to the positive upbringing of their children. According to Makinde (1984), modernparentsput excessive expectations on schools to provide solutions to issues related to indiscipline of their children. Given the scenario that childrenspendmost of their time ( 8 hours to be exact) in schools and an average of about four hourswith their parents at home, their personal and social development has become the responsibility of the institutions of learningso much that Career-Guidance and Counselling services have become an integral need for 
the secondary educationprogrammes. Guidance and Counselling services have become even more critical now than ever before. From this context, this study is underpinned on the notion that educational institutions require a more formal-professional structure of guidance and counsellingprogrammes to be initiated by trained counselors (Gysbers and Henderson 2001; Mapfumo,2001; Owino, 2005; UNESCO, 2002; Van-Niekerk, 2001). Consequently, Zimbabwe's secondary schools have been assigned the mandate by the Ministry of Primary and Secondary Educationto provide personal, social, educational and career-guidance and counselling to students. However, for all concerned parties to embrace the new philosophy regarding Career-Guidance and Counselling Services there is need for literature to put into perspective what works with Career-Guidance Counselling Services, how do we know it works and with what results? This study was one step towards achieving that objective, because itsought to establish the existence and effectiveness of the Guidance and Counselling services in providing students with personal, social, educational development and career guidance using theBulawayo Metropolitan Secondary Schools as a case study.

According to Mature\&Ndambuki (2003), adolescent students in secondary schools worldwide face numerous social, personal and academic problems at school and at home today than before. Many adolescent students are stressed and affected by HIV/AIDS pandemic as they care for the ailing and dying parents or relatives (Johnson, 2002:207), while some are coming from distressed families where parents are divorced or separated and where there is constant conflict within thefamily. According to Ndondo (2004), it is evident that some adolescent students in secondary schools experience child abuse, pressures from peers to concede to sexual practices before marriage, experiment with drugs and sex while at the same time parents and teachers expect them to excel in academic work. These conflicting pointers and problems affect students' academic careers/schooling to the extent that some drop out of school. School drop-out is considered a source of bigger future problemsthat include prostitution, drug abuse, crimes that lead to murder and unemployment. Because of these foreseeable problems, there is a need for effective implementation of Guidance and Counselling services in schools generally. Failure to provide guidance and counselling services maypromote increased numerous antisocial behaviours such as drug and alcohol abuse, irresponsible sexual behaviours, teenage pregnancies, gangsters, truancy, prostitution, increases in school dropouts and outbreak of school violence among many other problems, (Robinson, 1996; Nziramasanga, 1999; Steinberg\& Morris, 2001; UNESCO, 2002).

The psychosocial problems identified in other countries are prevalent in secondary schools situated in Bulawayo Metropolitan Province. In the Sunday News, Moyana (2013) revealed the Minister of Education acknowledged that Zimbabwean schools have high prevalence of HIV / AIDS and claimed that many students are either infected by the virus or look after affected ill family members. This revelation indicates that today's students face numerous stressors that may include among many others, the prevalence of HIV/AIDS, orphanage, lack of parental care. In another newspaper article, Moyana, (2013) reported that a number of the girls who are expected to sit for their O'Level examinations either get married or fall pregnant especially to male Zimbabweans who work in South Africa (injiva) and drivers who ferry goods to South Africa (omalayitsha). Early marriages, pregnancies and non-payment of school fees as a result of lack of unemployment opportunities among the majority of parents and guardians are a cause for concern in Bulawayo Metropolitan Province.MoyoandTshili (2013) notice that a number of secondary schools bar students from writing examinations or to continue with their education over outstanding tuition fees and levies including those under the Basic Education Assistance Module (BEAM). The Bulawayo community is concerned with teenagegirls' secondary education which is said to be disturbed by "sugar daddies" that create what are euphemistically referred to as "small houses" by using their financial status to subvert these young students for sexual gratification. Recently, it was reported by Chiwanga (2013) that prostitution is rife in Bulawayo involving female students as young as between the ages of 13 and 17, whoare driven by poverty or orphanage to leave school education to join the oldest profession. In another paper, it was also reported that in a certain boarding secondary school two female students were allegedly implicated in lesbian relationships. The incident had gone viral on the internet, and the lovers were seen fondling each other's breasts, kissing and cuddling. It was also reported that the same students were involved in several other nefarious activities such as smoking and drinking alcohol. The same story revealed that one of the girls who is believed to be the "man" in the lesbian relationship had violent disposition towards her partner. In another case, a teacher was allegedly reported to havesodomised students at a school who were later taken to Bulawayo United Hospitals for medical treatment (Moyo, 2013). A similar incident reported a secondary school male teacher who allegedly had a tendency to lureFormFour boys to watch pornographic videos after which he would sodomisethem. Such reports are of major concern especially considering that teachers are in locus parentis who are expected to uphold to moral values and protect children from all forms of abuse. In a study carried out by Mahlangu 2010 in South Africa it was concluded that sexually abused victims are traumatized and stigmatized as other pupils may call them with all sorts of denigrating names which affect them psychologically. It is within this context that teachers also need to be counseled to understand their role in the development of school children. In another paper, a seventeen year old bully male student was reported to have stabbed five school mates overajuicybottle. In another similar case, a Form Four male student, who wasallegedly under the influence of alcoholand drug abuse, beatupfour schoolteacherswho reported the 
case to the police (Chiwanga, 2013).A study carried out in Nigeria, Abdulahi, (2009) revealed that the major causes of drug and alcohol abuses include peer influence, lack of parental supervision, personality problems due to socio-economic conditions, availability of drugs in the communities. Publications of this nature help to raise concernsover the nature of guidance and counseling services being offered insecondary schools.

Schools are expected to provide and direct adolescent learners away from participating in the antisocial behaviorssuch as drug and alcohol abuse, prostitution and irresponsible sexual behaviours, teenage pregnancies, gangbangingandany other forms of school violence, truancy and school dropouts (Gysbers and Henderson, 2001; Nziramasanga, 1999; Robinson, 1996; Steinberg \& Morris, 2001). Studies by Owino (2005) and Nwachukwa (2007) revealed that ineffective Guidance and Counselling services in the present day schools system precipitates unprecedented rise in the crime wave, violence among students, fuels cultism, wrong career choices, and wrong subject combinations. The increase in diverse student problems such as these reported by Zimbabwean newspapers ten years after the introduction of Guidance and Counsellingprogramme in secondary schools are a clear indication thatsomething is not right with the implementation of the programmes which in turn emphasizes the importance of this study.

In order to come up with an effective Guidance and CounsellingProgramme, it is necessary to determine what support services and available resources are necessary to meet the needs of students, families and the communities. In Zimbabwe, the Ministry of Primary and Secondary Educationis not clear on the required professional qualifications of Guidance and CounsellingProgrammeimplementers which are assumed may have an impact on the future of students.Although the goals and objectives of Guidance and CounsellingProgramme are clearly articulated in the syllabus, the major concern is that the Ministry of Public Service Commission which is the employer of teachers distributed a correspondence in 2008 to government departments that it does not recognize Counselling degrees offered at Zimbabwe Open University for promotional and appointment opportunities. It is noticed that teachers who are holders of Bachelor Science Honours in Counselling and Masters in Science in Counselling are mostly trained at Zimbabwe Open University. The question is; what are the professional qualifications of teacher-counsellors who are mandated to implement Guidance and Counsellingprogramme by the ministries of Public Service Commission and Education, Sport and Culture?Stateddifferently,what is the role of teachers with BScHC or MSSC obtained at Zimbabwe Open University in secondary schools?It is noted that in secondary schools, Guidance and Counselling services are assigned as additional responsibilities to classroom teachers who are already overloaded with normal duties and in most cases without training in the implementation of such services. In developed countries, a professional guidance-counsellor is expected to be a licensed teacher withagraduate-level training in counseling who should demonstrate competence in the following areas; knowledge, skills and attitude (America School Counsellor Association, 1993).According to UNESCO, (2001), guidance and counselling teachers need to be equipped with professional skills required to design comprehensive guidance and counsellingprogrammes, provide services and use evaluation procedures that create a positive future for the learners. Gysbers and Henderson (2001) argue that if the teachers who provide Guidance and Counselling services are not buoyant enough to enable schools to provide effective Guidance and Counselling services then an ideal situation may remain "utopian'.

The attitudes and perceptions of heads of schools toward the implementation of Guidance and Counselling services play a significant role in the extent to which the intended goals are achieved. In Nigeria, studies indicate that guidance and counsellingprogrammes are not afforded due recognition by heads of secondary schools, teachers and relevant stakeholders (Abebe, 1988: Ademula, 1988: Bulus, 2001: Denga, 2001: Edet, 2008). Such heads of schools are said to have a tendency of withholding budgetary allocation for guidance and counselling services. Similarly, Rosenberg et al. (2009) in Chireshe (2006) found that some teachers used life orientation periods to do more 'important' subjects. Before the introduction and implementation of Guidance and Counselling subject in 2004 in secondary schools, Nziramasanga Commission (1999) had pointed out that, non-examinable subjects were ineffectively taught because they were regarded as inferior, such that they were merely conveniently time-tabled, but their time was usually used for the revision of examinable subjects. Similar studies have been carried out where heads of schools arecriticized for encouraging subject-teachers of examinable subjects to use the time allocated for guidance and counselling services for examinable courses/subjects; in Kenya, (Makinde, 1988: Nyamwake and Magaki, 2013), and in Zimbabwe, ( Chireshe, 2006). In Botswana, a study conducted by Shumba, Seotlwe and Montsi (2012) to examine the implementation challenges of Guidance and Counsellingservices revealed that teachers were not adequately equipped through training to teach the subject. The study also revealed that heads of schools did not supervise the implementation of the subject mainly due to lack of knowledge and skills on the subject content. The above studies generally indicate that factors such as lack of skills, misunderstandings regarding the implementation of guidance and counselling services, and confusion with regards to teachers and heads of schools in service delivery contribute to programme ineffectiveness.

In addition to human resources, the provisions of material resources or facilities and support services determine the extent to which the Guidance and CounsellingProgramme achieve its intended goals. Support 
services and available resources include human resources (staff, community members) material resources (programmes, audiovisuals, books computer facilities), financial support (budget, fund-raising, grants) time availability(planning and evaluation) community resources and school facilities(access to appropriate rooms for counselling activities), (Gysbers and Henderson, 2001).It is therefore the concern of this study to establish the extent to which Guidance and CounsellingServices in Bulawayo's Secondary Schools in Zimbabwe is timetabled and afforded the due recognition that it deserves by the school heads, teachers, parents and students despite being non-examinable.It is the concern of this study to establish the extent to which Guidance and Counselling services provided by Secondary Schools in Bulawayo Province assist learners in their social, personal and academic development as well as to enable them to make informed career selection decisions.

\subsection{Statement of the Problem}

Guidance and counselling services have been introduced in Zimbabwean Secondary Schools in order to enhance the personal, social and academic development of students and assist them to make realistic career choices and decisions. However, the success of this service in Zimbabwe has remained in doubt since there are limited studies and the existence of anti-socialbehaviour such as teenage pregnancies, teenage prostitution and abuse of alcohol, cheating in examinations has been reported in secondary schools in Bulawayo Metropolitan Province. The researcher has in addition noticed the existence of poor study habits, substance abuse and difficulty in coping with examination anxiety among adolescent learners, hence the importance of this study. The introduction of Career Guidance and Counselling services in Zimbabwe's Secondary schools has mandated the school authorities whose professional competence in the subject is skeptical, buoyed with lack of resources with the responsibility of guiding students' personal, social, academic development and in making informed career choices and decisions. This study therefore, sought to determine the extent to which Career Guidance and Counselling services in Zimbabwe's Bulawayo Metropolitan Secondary Schools assist students achieve personal, social and academic development and in making informed career choices and decisions.

\subsection{Purpose of the Study}

The purpose of this study was to determine the extent to which Career Guidance and Counselling services in Bulawayo Metropolitan Secondary Schools in Zimbabwe prepare secondary school students to achieve personal, social and academic development and make informed career choices and decisions for their future development.

\subsection{Research Questions}

BroadResearch Question

- To what extent do Guidance and Counselling services guide secondary school adolescent students in Bulawayo Metropolitan Province achieve personal, social and educational development and make informed career choice decisions?

\section{Specific Research Questions}

i) How do secondary school teacher-counsellors help them effectively implement guidance and counsellingprogrammes at their schools?

ii) What resources are availablein secondary schoolsthathelpteacher-counselors to effectively implement the guidance and counselingprogramme?

iii) How do the Guidance and Counselling services provided insecondary schools in the Bulawayo Province effectively assist learners achieve personal, social and academic development and help them make informed career choice decisions?

iv) What are the perceptions of secondary school heads, teachers and students of the benefits to students of the Guidance and Counselling services?

v) How do standardsused in Zimbabwe guide and counsel students in Bulawayo Secondary schools with current global standards of practice?

\subsection{Objectives of the study}

The objectives of the study will be to;

i) Establish whether secondary school teacher-counsellorshave requisite qualifications and training to effectively implement guidance and counselling services.

ii) Assess the adequacy of resources utilized in the implementation of Guidance and Counsellingprogramme in secondary schools in Bulawayo Metropolitan province.

iii) Establish the extent to which Guidance and Counselling services in Bulawayo Metropolitan province assist secondary school students achieve personal, social, educational development and make informed career choices. 
iv) Establish perceptions that are held by secondary school heads, teachers and students' about the significance of Guidance and Counselling services.

v) Establish the extent to which the provision of guidance and counselling services in theBulawayo Metropolitan Province are in tandem with current global trends.

\subsection{Significance of the Study}

It is envisaged that this study will benefit school guidance-counsellors, students, policy makers, administrators in the Ministry of Primary and Secondary Educationand researchers. The findings of this study will establish the extent to which secondary schools in Bulawayo Metropolitan Province possess Guidance and Counselling services to achieve students' personal social and academic development. The study will assist educational authorities to check and stem out wastage and stagnation in educational system such as the failure by students to complete their studies. Therefore, the recommendations of this study have the ability toassist education policy makers and the secondary school leadership in planning and making appropriate decisions to strengthen guidance and counseling services that have the capacity to achieve goals for which theprogrammes are designed. Parents and guardians willalso benefit from the findings to this study since their efforts in counselling their children would be supplemented. Finally, this study has the potential to create awareness on the importance of effective guidance and counselling services in secondary schools in Bulawayo Metropolitan Province and other provinces of Zimbabwean provinces or other countries.

\subsection{Assumptions of the Study}

The following assumptionsguidedme during data collection processes;

i. Career-Guidance and CounsellingProgramme is promoted in secondary schools to prepare students for post-secondary education

ii. The implementers of Career-Guidance and Counselling services have relevant expertise to effectively teach the subject for the benefit of the students

iii. The respondents will be willing to provide honest responses that reflect the information stipulated in the questionnaire, and interview guide and the focus group discussions. This is hoped will enhance valid interpretations, conclusions and recommendations.

\subsection{Delimitations}

This study assessed the implementation of Guidance and CounsellingProgramme inMzilikazi District secondary schools situated in Bulawayo Metropolitan Province. Secondary schools situated in Bulawayo Metropolitan Province comprise urban schools (either directly controlled by the government or private schoolsadministered by church organizations, or individuals) and peri-urban schools established by the government in resettlement farms around the city.

\subsection{Limitations of the Study}

The following factors were posed as the limitations of the this study;

i. Some interviewees might have found the study to be sensitive and became suspicious of their involvement in the study especially in these days of political sensitive issues. The researcher assured the research participants that the findings of the study would not be reported on the basis of individual institutions but rather on the overall reports of the respondents in the different institutions

ii. There might have been some respondents who exhibit only socially acceptance views. During collection of the qualitative data, some of the interviewees might have been defensive when asked questions relating to their service. To overcome this, the researcher assured them that the data would be treated confidentially and thatanonymitywould be guaranteed through the use of pseudonyms (Creswell, 2007)

\subsection{Definition of Terms}

Assessment: In this study the term assessment refers to an evaluative process that is goal oriented either quantitatively or qualitatively measured against stated objectives in the Guidance and Counseling Syllabus of 2003.

Guidance:It is the professionalized aid given to help secondary school students in order to become useful and worthwhile citizens. It involves guiding, informing, directing, and assisting students in making choices, and solving problems thy encounter in their learning situations.

Counselling:It is a process by which trained individuals offer help to individual students in one to encounter. In counselling, information is given but it deals more intensely with personal and emotional issues. The students are assisted to understand their psychological challenges, thinking and behaviours. The counselee is expected to be self-directed and self-actualized hence motivated to solve their problems. 


\section{Theoretical Framework}

A theoretical framework offers a 'map' of the research process that guides the researcher in investigating the nature and scope of the study in relation to the research questions, objectives, hypothesis and the purposes of the study. The theoretical framework of this study anchors on the developmental and systems approaches. The goal of school guidance and counseling is to promote development of the whole individual in order to ensure student 'flourishes' (Corey, Corey and Callahan, 2007). A flourishing student is the one who is most fully receiving the benefits of his/her educational experience and achieving personal potential. Moreover, the goal of school guidance and counseling is not only to support positive healthy human development but also to help create a school environment that develops a student's right to flourish by achieving personal/social goals. Using 'strengths based' framework (Galassi and Akos, 2007) school guidance and counseling programmes should have two goals; to foster the developmental assets of the students (Benson, Scales and Mannes, 2003) and to reinforce positive factors that build resiliency in students(Werner and Smith, 1992). Research by Benson (1997) has identified four categories of developmental assets which include external assets (support, empowerment, boundaries and expectations) and four groups of internal assets (educational commitment, values social competencies and positive identity). The resiliency literature (Bernard, 2004) has identified protective factors that can be implemented at individual and system level. Henderson and Milstein (1996) identified protective factors that fit the school guidance and counseling programme;

- Prosocial bonding which involves strengthening connections between students and adults within the school/community and increasing student's involvement in school activities.

- School policies that teach students appropriate behaviors.

- Life skills which focus on the academic, career and personal/social competencies students need to be successful in their lives.

- Provision of programmes which support students' growth.

- $\quad$ Peer directed programmes.

The philosophy underlying Guidance and Counseling Programme is that it must be built on a comprehensive, research-oriented, functional approach that suit the developmental needs of students ( Myriek, 1993). Four possible developmental approaches to Guidance and Counseling include; crisis, remedial, preventive and growth (ASCA)

Bronfenbrenner's (1979) socio-ecological systems theory posits that human development is shaped through an interaction between the individual and their environment. According to the systems perspective, individuals influence and are influenced by the systems in their environment. Student and school problems are a function of the pattern of interaction between the individual and their environment (Woolfe and Dryden, 1996). Subsequently, in order to eliminate problems that block students from flourishing, those problems must be addressed on many levels and in the context of a 'system' that includes not only the student and the school but also the student's environment (family and community).

This study intended to assess how schools work within and between multiple systems at different levels, including the student, school and community. Since students influence and are impacted by the systems of which they belong (Bronfrenbrenner, 2005: Carrns and Carns, 2005: Hernades and Seem, 2004) a useful strategy for working with students and their families is to adopt a broader or holistic perspective. Families and schools are interconnected systems, students, therefore bring to schools their family system dynamics, while trying to negotiate the complexities of the classroom and school system (Amatea and Brown, 2003: Caffery, Erdman and Cook, 2000).

Guidance and Counselling services which integrate notions underlying holistic perspectives on student development include developmental conceptualism and dynamics of systems approach (Lerner, 2002). What this entails is that guidance -counsellors and other educators (e.g. teachers, heads of schools and administrators) and parents including relevant stake-holders are encouraged to help students reach career, academic, personalsocial developmental competencies. In light of Bronfrenbrenner's system perspective on obstacles of educational achievement, school counsellors are required to make greater utilization of resources inside as well as outside the classroom (Alderman, 2005). The 'locus of pathology' ceases to be the problem of the individual but rather from the context in which they occur (Goldenberg and Goldenberg, 1980). In summary, a systemic perspective appears to be an effective framework for delivering guidance and counseling in schools. The school guidance -counselor cannot afford to solely approach problems on an isolated, individual student level but rather must operate at a higher system level working for change inside/outside the school while accessing support and resources in the greater community in order to overcome impediments to student flourishing (ASCA,2005: Hernandez and Seem,2004). School guidance-counselors or teachers responsible for programme implementation should design programmes and services that meet the needs of students at various developmental stages of human growth. 


\subsection{Conceptual Framework}

Guidance and Counselling has been conceptualized as an essential programme that provides all students the opportunity for optimal development (Gysbers and Henderson, 2001: ASCA, 2004). Bhusumane (1993) posited that Guidance and Counselling is a programme of services to individuals based on the needs and the influence of environmental factors. Guidance and Counselling is a professional field which has a broad range of activities, programmes and services geared toward assisting individual students to understand themselves, their problems, school environment and their world and also to develop adequate capacity for making wise decisions (UNESCO, 2001). An effective Guidance and Counsellingprogramme provides developmental opportunities and experiences that address three central student development areas: learning (personal/social) learning to learn (academic), and learning to work (career), Dahir, 2001). It includes sequential activities designed to address the needs of all students by helping them acquire competence in the knowledge of self and others, in identifying their educational goals, and in their own career development.

\section{ResearchMethodology}

This study used a descriptive survey which is quantitatively and qualitatively paradigmatic by corroborating the elements from positive approach and the constructivist/phenomenological orientation. The descriptive survey enables the researcher to obtain in depth information which can be used to facilitate the generalization of findings to the larger population(Borg \&Gall,1996). This design was found to be ideal for gathering data for purposes of describing certain perceptions ,opinions, attitudes ,relationships and orientations held by a population too large to observe directly(Leedy\&Ormrod,2005:Tshuma \&Mafa ,2013). The research in this study used survey questionnaires and qualitative interview guides to solicits views and opinions about the impact of Guidance and Counselling services in secondary schools through structured closed -question items and open -ended questions. To complement the function of survey questionnaire a qualitative interview was used.

\section{Population}

The population chosen from the Mzilikazi District in Bulawayo comprised of the following five schools which had a total of 6000 students, 150 teachers and five heads of schools

\section{Sample}

The population of students (6000) and teachers (150) was divided into categories through stratified random sampling. One hundred students and thirty teachers were randomly stratified and five heads of schools were chosen to be research participants through convenience sampling.

\section{Data Collection Procedures}

The researcher hand delivered questionnaires to five secondary schools .Teachers responsible for teaching Guidance and Counselling subject who were part of the sample distributed questionnaires to their colleagues and students who were randomly selected for the research study: Permission to the administrator questionnaires was sought from headmasters.

\section{Data Presentation, Analysis and Interpretation \\ Benefits of Guidance and CounsellingProgramme to Secondary School Students}

Table 1.Distribution to Heads of Schools, Teachers and Students

\begin{tabular}{|c|c|c|c|c|c|c|c|c|c|c|c|c|}
\hline \multirow{3}{*}{$\begin{array}{l}\text { Statement } \\
\text { Does Guidance include the following }\end{array}$} & \multicolumn{4}{|c|}{$\begin{array}{l}\text { Head of Schools } \\
n=5\end{array}$} & \multicolumn{4}{|c|}{$\begin{array}{l}\text { Teachers } \\
\mathrm{n}=30\end{array}$} & \multicolumn{4}{|c|}{$\begin{array}{l}\text { Students } \\
\mathrm{n}=100\end{array}$} \\
\hline & \multicolumn{2}{|c|}{ YES } & \multicolumn{2}{|c|}{$\mathrm{NO}$} & \multicolumn{2}{|c|}{ YES } & \multicolumn{2}{|c|}{$\mathrm{NO}$} & \multicolumn{2}{|c|}{ YES } & \multicolumn{2}{|c|}{$\mathrm{NO}$} \\
\hline & $\mathrm{f}$ & $\%$ & $\mathrm{f}$ & $\%$ & $\mathrm{f}$ & $\%$ & $\mathrm{f}$ & $\%$ & $\mathrm{f}$ & $\%$ & $\mathrm{f}$ & $\%$ \\
\hline Teaching about Different Careers & 1 & 20 & 4 & 80 & 12 & 40 & 18 & 60 & 20 & 20 & 80 & 80 \\
\hline $\begin{array}{l}\text { Teaching about Different study options in } \\
\text { tertiary institutions }\end{array}$ & 1 & 20 & 4 & 80 & 10 & 33 & 20 & 67 & 25 & 25 & 75 & 75 \\
\hline $\begin{array}{llll}\begin{array}{l}\text { Counselling } \\
\text { problems }\end{array} & \text { Students } & \text { on } & \text { Personal/social } \\
\end{array}$ & 1 & 20 & 4 & 80 & 13 & 43 & 17 & 57 & 10 & 10 & 90 & 90 \\
\hline Teaching about Appropriate Behavior Practices & 1 & 20 & 4 & 80 & 9 & 10 & 21 & 90 & 20 & 20 & 80 & 80 \\
\hline
\end{tabular}

The above results revealed that only one secondary school out of five teach Guidance and Counselling . This also indicates that about $80 \%$ of the secondary schools in Mzilikazi District in Bulawayo have not complied with the Ministry of Education ,Sport and Culture in the implementation of Guidance and CounsellingProgramme and its services in secondary schools. The four heads whose schools have not fully complied with the ministry of education policy, during interview, revealed that Guidance and Counselling Subject lacks relevant resources 
(human personnel -qualified teachers and material resources (books, stationary, rooms for counselling)which are needed in the teaching of the subject. This finding was supported by teachers and students $(60 \%$ and $80 \%)$ respectively indicated that students are not taught about failure career choices .To support this position sixtyseven percent of the teachers and seventy- five percent of the students concurred that students are not conscientized about the study programmes offered in tertiary institutions that exist in Bulawayo. This study established low-levels of teaching students on appropriately acceptable behaviors (heads $20 \%$, teachers $10 \%$ and students 20\%).However, teachers were of the opinion that moral values and cultural-traditional norms were taught through subjects like; Religious and Moral Education and Bible Knowledge. It was also noted that these subjects were not appealing to most students who were interviewed, except for those who intended to do theological learning programmes after completing secondary education.

Table 2. Distribution to Teachers on Teacher- Counselor Qualifications $\quad \mathbf{n}=30$

\begin{tabular}{|l|l|l|}
\hline Qualifications & n(f) & \% \\
\hline Degrees in Guidance \&Counselling & 1 & 3 \\
\hline Diplomas in Guidance \&counselling & 4 & 13 \\
\hline Certificates in Guidance and Counselling & 5 & 17 \\
\hline No training in Guidance \&Counselling & 20 & 67 \\
\hline
\end{tabular}

Table 2 shows that only one teacher had a degree in Guidance and Counselling. During interviews it was revealed that the Ministry of Public Service Commission does not recognize Counselling degrees, (BSCHC and MSCC) offered at Zimbabwe Open University. Consequently, such degree holders, that is, teachers who were holders of such degrees were reluctant to teach the subject. Heads of schools interviewed were of strong opinion that schools lacked qualified guidance and counselling teachers, however, they could not engage degree holders from Zimbabwe Open University without approval from the relevant authorities. It was also revealed that the major losers in such a scenario where there is conflict of interest among decision-makers were students and their parents.

Table 3. Resources Available to Teach Guidance and Counselling- Distributions to Heads of Schools

\begin{tabular}{|l|l|l|l|l|}
\hline Statement & \multicolumn{2}{|c|}{ YES } & \multicolumn{2}{|c|}{ NO } \\
\cline { 2 - 6 } & $\mathrm{n}$ & $\%$ & $\mathrm{~N}$ & $\%$ \\
\hline Allocation of funds for the programme & $\mathbf{0}$ & $\mathbf{0}$ & 5 & 100 \\
\hline Provisions of In-service training & & & & \\
\hline Possession of Guidance and Counselling Conference & 0 & 0 & 5 & 100 \\
\hline
\end{tabular}

The five heads of schools revealed that they did not have qualified Guidance and Counselling personnel. It was also established that no in-service training programmes were organized for teachers to equip them with basic Guidance and Counselling skills. The schools also do not have budget allocation for the Guidance and CounsellingProgramme. During the interview, heads of schools also revealed that secondary schools lack the following items; journals, magazines, pamphlets and brochures from tertiary institutions around Bulawayo as well as those from other regions, and ICT resources. The only noticeable, available and relevant resource was the school syllabus from the Ministry of Education, Sport and Culture. Teachers were interviewed to establish their attitudes towards Guidance and CounsellingProgramme. Teachers were of the view that the subject was not recognized because of the following:

- It was non examinable hence a worst of time.

- One school which claimed to provide Guidance and CounsellingProgramme criticized lack of resources as the major barrier for effective implementation.

- Generally heads of schools concurred on their views that the Ministry of Education, Sports, Arts and Culture should provide in-service courses to instill confidence among programme implementers.

- Heads of schools did not supervise the implementation of the programme on what they considered to be the lack of time, resources and support from the government.

- Students viewed the subject as irrelevant since it was non-examinable and was misconstrued as a worst of study time in preparation for examinable subjects.

\section{Conclusions}

From the findings of this study, the following were concluded:

- The students from Mzilikazi District Secondary schools did not benefit from Guidance and CounsellingProgramme since the services were not fully implemented in most schools, that is, about eighty-percent of the secondary schools. Twenty percent of the schools which implemented the 
programme lacked both human and material resources-rendering the initiative inefficient and worthless.

- Wherever the subject was taught, it failed to achieve its goals and objectives as stipulated in the syllabus.

- Heads of schools, teachers and students lacked positive attitudes and to some, it was a worst of time.

The following were the recommendations of this study:

\section{Recommendations}

- The Ministry of Public and Commission which employs civil-servants inconjunction with the Min. of Education, Sports, Arts and Culture should consider employing qualified teachers with training in guidance and counselling knowledge and skills to implement the subject.

- The Ministry of Education, Sports, Arts and Culture should revisit its educational goals and policies such as budget allocation, provision of both human and material resources before the introduction of any programme/ subject.

- Heads of schools and educational officers should effectively supervise the implementation of the Guidance and CounsellingProgramme to achieve its aims, goals and objectives.

- Relevant Guidance and Counselling facilities should be availed to enhance relevant /effective implementation of its services.

\section{References}

[1]. Achebe, C. (1986) The Role and responsibilities of Secondary School Principals in the School Guidance Programme. The Nigerian Journalof Guidance and Counseling 2. 1-11.

[2]. ASCA. (2012)The ASCA national model: A framework for a counselor programs ( $3^{\text {rd }}$ ed)...Alexandra, VA: American School Counselor Association.

[3]. Bulus,1.(2001).Counselling Education Nigeria: The Post Presents and Future Challenges. ABU Journal of Counselling and human Development 1(1),284-299

[4]. Chireshe,R .(2012).School of Guidance and Counselling Needs Assessment In Zimbabwean Secondary Schools.14:17-24.

[5]. Denga, D.I.(2001).Guidance and Counselling In School and Non-School Settings.2 ${ }^{\text {nd }}$ ed. Port Harcourt Double Diamond Publications.

[6]. Egbochuku, E.O.(2012).Remedy to the Inadequate Representation of Guidance and Counselling in the National Policy of Education Berun

[7]. European Center For Development of Vocational Training (CEDEFOP)(2011).Working and Ageing: Guidance and Counselling for Mature Learners: Luxembourg; Publications for the European Union.

[8]. Galassi, J.P\&Akos,P.(2004).Developmental Advocacy. Twenty-first century school

[9]. Gysbers, N.C.(2004). Comprehensive Guidance and Counselling, 8, 1-14

[10]. Gysbers, N.C.7 Henderson, P . (2001). Comprehensive Guidance and CounsellingProgrammes; Arch history and a bright future

[11]. Professional School Counselling. Vol 4.246-256

[12]. Mahlangu,V.(2011).Dilemma in School District in Managing Career Counselling in South Africa Journal of Emerging.

[13]. Trends in Educational Research and Policy Studies 2:239-245.

[14]. Mapfumo,J.(2002)Career Perceptions and visions of Boys and Girls in Secondary Schools in Zimbabwe ;Some Implications for TeachersAndParents.Mutare. Africa University

[15]. Mbiti ,M.(1981).An Introduction to Education .Nairobi: Oxford University Press.

[16]. Mutie,H.\&Ndambuki,W.(2003). The Philosophy behind Guidance and Counselling. Nairobi: Gupa Press

[17]. Nwachukwu,D.N.(2007), The Teacher Counselor For Today's School.Calabar University of Calabar Press .

[18]. Othman,A.H.(2001). Guidance and Counselling; An Emerging Profession .Cross- Cultural PsychologyBulletin, 35, 18-222

[19]. Salim, S.(1998).Psychology Applied to MordenLife;Adjustment in the 21 Century97th ed.).Upper Siddle River ,N.J;Thomson Learning

[20]. Schmidt, J.J.(2008). $5^{\mathrm{TH}}$ eds .Comprehension Programmes of Responsive Services for AU Students. West post Allyn\& Bacon.

[21]. Tamilenthi, S\&Mbewa (2012).The Perception of Guidance and Counselling in Petauke District of Eastern Province of Zambia 2.13-18

[22]. UNESCO (2000). Guidance Module 1. France: Agzi Communication.

[23]. Wendy \&McMahon, M.(2006).The Systems Theory Framework of Career Development and Counselling :International Journal For Advancement of Counselling 28:153-166. 